\title{
COMMUNITY PARTICIPATION IN DEVELOPING FACILITIES AND INFRASTRUCTURE STANDARDS IN ISLAMIC ELEMENTARY SCHOOL OF KEEROM-PAPUA
}

\author{
Talabudin Umkabu ${ }^{1}$ \\ Bahaking Ramah ${ }^{2}$ \\ Muzakkir ${ }^{3}$ \\ St. Azisah ${ }^{4}$ \\ IAIN Fattahul Muluk Papua ${ }^{1}$ \\ Lecture at The Faculty of Tarbiyah and Teacher Training Alauddin State Islamic \\ University Makassar, Indonesia ${ }^{2,3,4}$ \\ abiyansajayahoo.co.id ${ }^{1}$ \begin{abstract}
of standard facilities and infrastructure for Islamic Elementary School of Keerom-Papua. This type is qualitative research, the research approach is a phenomenological perspective and a descriptive analysis approach, data sources are primary data and secondary data, data collection techniques through observation, interviews, and documentation, research instruments namely, researchers as key instruments, observation guides, interview guides and reference documentation, processing techniques and data analysis, namely data reduction, data presentation, conclusion and verification, data validity testing, namely triangulation techniques, checking the correctness of information, discussing and consulting data, and extending the research time. The results showed community participation in the development of standard facilities and infrastructure at Islamic Elementary School of Keerom-Papua concluded that the community was enthusiastic about participating in building mushallah/mosque and procuring canteens and greenhouses. Boarding and equalizing the madrasah yard, fencing the front door of the madrasah, making madrasah fish pond gardens, and the land used as the location for the construction of madrasah and mosques are the provision of traditional leaders (non-Muslims) and the procurement of sports equipment, while the procurement of the main facilities, specifically for Islamic Elementary School The private sector shows that there is participation but it is not maximal while public Islamic Elementary School have not seen maximum community participation, it is due to a lack of public awareness of a sense of responsibility in developing madrasah, and building communication to exchange opinions with the community about the importance of community participation in developing madrasah as a charity Jariyah and social activities.
\end{abstract} \\ Abstract: This paper describes community participation in the development
}

Keywords: Community Participation; Infrastructure; Keerom Papua

\section{INTRODUCTION}

In the context of national education, standards are needed that must be achieved within a certain period to achieve educational goals. Strategic steps can be achieved through various activities in the educational process. If there are no 


\section{Talabudin Umkabu, Bahaking Ramah, Muzakkir, St. Azisah}

benchmarks or yardsticks that are used as guidelines, of course there will be chaos in education because they have no direction. The statement regarding the need for a national education standard according to Tilaar ${ }^{1}$ is;

“a) National education standards are political demands, b) National education standards are demands of globalization c) National education standards are demands of progress. It is further argued that the function of national education standards is a) measuring the quality of education, b) structuring educational problems, c) formulating strategies and development plans after data is obtained from national learning evaluations such as national exams."

About the National Education Standards, it is argued that the National Education Standards have a function as the basis for planning, implementing and supervising education in the context of realizing quality national education, and aiming at ensuring the quality of national education to educate the nation's life and shape the national character and civilization of good quality, and aims to guarantee the quality of national education in the framework of the intellectual life of the nation and to form a dignified national character and civilization. This means that educational standards are the foundation for building Indonesian education to achieve the quality of Indonesian education.

The definition of national education standards is explained in the Government Regulation of the Republic of Indonesia Number 32 of 2013, that: National Education Standards are the minimum criteria regarding the education system in all jurisdictions of the Republic of Indonesia. ${ }^{3}$

The PP states that the national education standard is a means for guaranteeing and controlling the quality of education by the National Education standards, evaluating, accrediting and certifying the quality of education services. The scope of national education standards includes content standards, process standards, graduate competency standards, teacher standards and education personnel, the standard of facilities and infrastructure, management standards, financing standards, assessment standards. With these national standards, the direction of improving the quality of Indonesian education will be better.

In Government Regulation Number 32 of 2013 concerning Amendments to Government Regulation Number 19 of 2005 concerning National Education Standards covering, among others:

1. Standard content is criteria scope of material levels achieving competency graduates which and the type of education.

2. Standard process is the criteria regarding the implementation of learning in the educational unit.

3. Competency standards for graduates are a set of attitudes, knowledge, and skills that students must possess, live and master after learning a subject matter, completing a program, or completing a certain educational unit.

4. Education standards and educational personnel are criteria regarding preservice education and eligibility as well as mental, as well as in-service education.

\footnotetext{
${ }^{1}$ H.A.R. Tilaar, Paradigma Baru Pendidikan Nasional (Jakarata: Reneka Cipta, 2009), h. 289.

${ }^{2}$ H.A.R. Tilaar, Paradigma Baru Pendidikan Nasional, h. 289.

${ }^{3}$ Republik Indonesia, PP Nomor 32 Tahun 2013 tentang Perubahan atas Peraturan Pemerintah Nomor 19 Tahun 2005 tentang Standar Nasional Pendidikan, pasal 1, ayat 1., h. 2.
} 
5. Standard facilities and infrastructure are criteria regarding study rooms, places for sports, places of worship, libraries, laboratories, workshops, places to play, places for creation and recreation, as well as other learning resources, which are needed to support the learning process, including the use of information technology and communication.

6. Management standards are criteria regarding the planning, implementation and supervision of educational activities at the educational unit, district/city, provincial, or national level to achieve efficiency and effectiveness of education delivery.

7. Financing standards are criteria regarding the components and the amount of the educational unit operating costs which are valid for one year.

8. Assessment standards are criteria regarding mechanisms, procedures and instruments for assessing student learning outcomes. ${ }^{4}$

As has been stated, the management of schools in Indonesia is directed towards achieving the minimum standards, as stated in the national education standards. This paper tries to describe community participation in the development of standard facilities and infrastructure for Islamic Elementary School of Keerom-Papua

\section{LITERATURE REVIEW}

National Education Standards-based on Government Regulation No. 32 of 2013 are as follows: (1) Standard content; (2) Standard process; (3) Competency standards of graduates; (4) Teachers and education staff standards; (5) Standard facilities and infrastructure; (6) Management standards; (7) Standard financing; (8) Educational assessment standards.

Standard for Facilities and Infrastructure are criteria regarding study rooms, places of exercise, places of worship, libraries, laboratories, workshops, places to play, places for creation and recreation as well as other learning resources, which are needed to support the learning process, including the use of information and communication technology. ${ }^{5}$ Educational facilities, namely equipment directly used for the educational process, such as desks, chairs, classes and teaching. Educational infrastructure is a facility that indirectly supports the education process, such as yards, gardens, parks. ${ }^{6}$

Furthermore, the infrastructure referred to includes land, classrooms, education unit leadership room, educator room, administration room, library room, laboratory room, workshop room, production unit room, canteen room, power and service installation, sports area, worship, a place to play, a place to create, and other spaces/places needed to support an orderly and sustainable learning process. ${ }^{7}$

Educational facilities are all facilities needed in the learning process, both moving and immobile so that the achievement of educational goals can run smoothly,

\footnotetext{
${ }^{4}$ Republik Indonesia, Peraturan Pemerintah Nomor 32 Tahun 2013, pasal 1, ayat 5-12.

${ }^{5}$ Peraturan Pemerintah Republik Indonesia Nomor 32 Tahun 2013 Tentang Perubahan Atas Peraturan Pemerintah Nomor 19 Tahun 2005 Tentang Standar Nasional Pendidikan, h. 3.

${ }^{6}$ E. Mulyasa, Pedomanan Manajemen Berbasis Madrasah, h. 49.

${ }^{7}$ Undang-undang dan Peraturan Pemerintah RI., h. 178.
} 


\section{Talabudin Umkabu, Bahaking Ramah, Muzakkir, St. Azisah}

orderly, effectively and efficiently. ${ }^{8}$ Meanwhile, Sri Minarti said, educational facilities are equipment that is directly used for the educational process, such as tables, chairs, classes and teaching media. Meanwhile, educational infrastructure is a facility that indirectly supports the education process, such as yards, gardens and parks. ${ }^{9}$

From a description of educational facilities, it can be classified, namely from the point of view: move or not during use; and its relationship with the learning process. In terms of whether they are used up or not, there are two kinds of educational facilities. Used educational facilities and durable educational facilities. Consumable educational facilities are materials or tools that if used can be used up in a relatively short time. For example, chalk, printer ink and so on. There are also educational facilities that are durable, namely materials or tools that can be used continuously or repeatedly in a relatively long time. For example tables, chairs, computers, atlases, globes and sports equipment.

Mobile educational facilities are educational facilities that can be moved or transferred according to the needs of the wearer. For example, tables and chairs, filing cabinets, and practical tools. Then, for immovable educational facilities are educational facilities that cannot be moved or are very difficult to move, for example electric cable lines, lines from the Regional Water Company (PDAM), and permanently installed LCDs.

About the learning process, educational facilities can be divided into three, namely learning tools, teaching aids, and teaching media. Learning tools are tools that can be used directly in the learning process, for example books, teaching aids, stationery, and practical tools. Teaching aids are educational aids that can be in the form of actions or objects that can concrete learning material. Learning materials that were previously abstract can be concretized through teaching aids so that students receive lessons more easily. Teaching media is an educational tool that functions as an intermediary in the learning process to increase effectiveness and efficiency in achieving educational goals. There are three types of teaching media, namely visual, audio and audiovisual.

Meanwhile, educational infrastructure in madrasah can be classified into two types, first, educational infrastructure which is directly used for the teaching and learning process, such as the theory room, library room, skills practice room, and laboratory room. Second, madrasah infrastructure which is not used for teaching and learning, but directly supports the teaching and learning process. For example, office space, madrasah canteen, land and roads to the madrasah, restrooms, madrasah health business rooms, teachers' rooms, madrasah principal rooms and parking lots.

Facilities and infrastructure are components in the learning process that contain the potential of each student in each education unit, both formal and nonformal. Educational facilities and infrastructure are also often referred to as school/madrasah facilities or equipment which are summarized in school/madrasah

\footnotetext{
${ }^{8}$ Suharsimi Arikunto dan Lia Yuliana, Manajemen Pendidikan (Yogyakarta: Aditya Media, 2008), h. 273.

${ }^{9}$ Sri Minarti, Manajemen Sekolah: Mengelola Lembaga Pendidikan Secara Mandiri (Yogyakarta: Ar-Ruzz Media, 2011), h. 251.
} 
equipment management which can be interpreted as a collaborative process for the utilization of all educational equipment effectively and efficiently. ${ }^{10}$

The definition of facilities and infrastructure itself is equipment or goods, both movable and immovable, which are used directly for the educational process, while infrastructure is all devices that are not directly used for the educational process. Facilities and infrastructure are a necessity that must be available to support learning activities and improve the quality of education and to realize the goals of national education.

Based on Government Regulation Number 19 of 2007, it explains that schools/madrasah establish written policies regarding the management of facilities and infrastructure. The management program refers to the Standard for Facilities and Infrastructure including:

“1) Planning, fulfilling and utilizing educational facilities and infrastructure; 2) Evaluating and maintaining facilities and infrastructure so that they continue to function to support the education process; 3) Complete learning facilities at each grade level in schools/madrasah; 4) Compile a priority scale for the development of educational facilities by the educational objectives and curriculum of each level; 5) Maintain all physical facilities and equipment with due regard to environmental health and safety." 11

From the description above, it can be concluded that the principles of management of educational facilities and infrastructure include: goals, efficiency, administration, cohesiveness and responsibility. Standardization of madrasah infrastructure is imperative because it is to spur education managers, administrators and units to improve their performance in providing quality education services.

\section{RESEARCH METHODOLOGY}

This type is qualitative research, the research approach is a phenomenological perspective and a descriptive analysis approach, data sources are primary data and secondary data, data collection techniques through observation, interviews, and documentation, research instruments namely, researchers as key instruments, observation guides, interview guides and documentation references, data processing and analysis techniques, namely data reduction, data presentation, conclusion and verification, data validity testing, namely triangulation techniques, checking the correctness of information, discussing and consulting data, and extending research time.

\section{RESULTS AND DISCUSSION}

The success of learning in madrasah is supported by the effective and efficient utilization of all educational facilities and infrastructure in madrasah. The existing facilities and infrastructure need to be utilized and managed for the benefit of the learning process.

\footnotetext{
${ }^{10}$ Ibrahim Bafadal, Manajemen Perlengkapan Sekolah, Teori dan Aplikasi (Cet. II; Jakarta: Bumi Aksara, 2004), h. 2.

${ }^{11}$ Peraturan Menteri Pendidikan Nasional R.I, Nomor 19 Tahun 2007 tentang Standar Pengelolaan Pendidikan oleh Stuan Pendidikan Dasar dan Menengah, (salinan lampiran) h. 10.
} 
Educational facilities and infrastructure are an important component in education and become one of the eight National Education Standards. Such is the importance of educational facilities that every institution is competing to meet the standards of educational facilities and infrastructure to improve the quality of the learning process. Not only that, the completeness of educational infrastructure is one of the attractions for prospective students.

To achieve these results, facilities and infrastructure are needed that support the success of the teaching and learning process in madrasah, starting from the types of equipment needed to how to procure and distribute, equipment and supervision, and use and maintenance so that existing facilities and infrastructure can be used according to their designation maximally.

Educational facilities and infrastructure in madrasah are not managed with sufficient knowledge, so there is often accuracy in management. The inaccuracy of the management of educational facilities and infrastructure regarding the method of procurement, the person in charge and management, maintenance and maintenance, and elimination. That is why community participation is needed in implementing the development of Islamic Elementary School of Keerom-Papua.

The community is a madrasah partner in implementing the development of Islamic Elementary School in Keerom-Papua, because madrasah is an integral part of society. Cooperation between the two of them is very important to increase involvement, care, ownership, and operational support, both moral and financial. The relationship between madrasah and community has been centralized, but its implementation has not been optimal. The problem is that the madrasah can further optimize and increase the intensity and extension of their relationship with the community.

Community participation in the development of Islamic Elementary School in Keerom-Papua, especially those related to the development of standard facilities and infrastructure carried out by residents as individuals as well as social groups and organizations, taking part in developing standard facilities and infrastructure at Islamic Elementary School of Keerom-Papua.

\section{Development of Main Facilities and Infrastructure/Learning Tools}

Educational facilities and infrastructure in madrasah can be classified into two types, first, educational infrastructure which is directly used for the teaching and learning process, such as the theory room, library room, skills practice room, and laboratory room. Second, madrasah infrastructure whose existence is not used for the teaching and learning process, but directly supports the teaching and learning process. For example, office space, madrasah canteen, land and roads leading to madrasah, restrooms, madrasah health business room, teacher room, headroom and parking lot.

In connection with the foregoing, the researcher interviewed with the head of the Islamic Elementary School (Arso III) as follows:

"Regarding the development of classrooms and leadership rooms, as long as I was the head of the madrasah there was no provision for classes, and the leadership room came from parents or the community. What I see is community participation in the construction of mushallah, there is also through the district government policy. Keerom about the Adiwiyata program, Adiwiyata is a 
program of the State Ministry for the Environment with the Ministry of National Education, which aims to create good conditions for MIN to become a place for learning and awareness for MIN residents (teachers, students \& surrounding residents) so that later MIN residents can take responsibility to save the environment. $S$ hile the procurement of classroom and boardroom there was no community, I think it was hard to expect from the public because of the public perception about the free education program that all government expense, that cause the madrasah feel the weight anyway if you want to ask the public, let alone a madrasah it seems government-owned." ${ }^{\prime 2}$ said that:

Furthermore, the Head of Islamic Elementary School (MIN) of Keerom-Papua

"Adiwiyata basic principles such as participation, which is expected madrasah communities (communities, and citizen's madrasah) are involved in the management of the madrasah which covers the entire process of planning, implementation, and evaluation s e custom responsibilities and roles. La Hardi further explained that the Adiwiyata program was divided into 21 Pokja. Among them are Greenhouse Working Group, Green House Working Group, Recycling Working Group, Fish Pond Working Group, Waste Bank Working Group, Working Group, Living Pharmacy, Compost Working Group, Slogan Working Group, Garden Arrangement Working Group, Environmental Documentation Working Group, Canteen Working Group, Toilet Working Group, Nursery Working Group, Working Group health, school garden working group, environmental making working group, environmental culture working group, environmental day working group, extra-curricular working group and security working group, and monev team. Most of what is accomplished by each of these working groups are the direct involvement of the community in helping to provide education to madrasah students and teachers according to their respective expertise."

Besides, community participation in the form of funds and energy and even thoughts, this can be seen through the material hoarding and equalization of the schoolyard as an open space for student/student learning activities, in addition to equal distribution of the main madrasah page, there is also a contribution from the community in the form of fence madarasah main entrance. As stated by the head of Madasarah.

"The participation or participation of the community (parents of students and even the wider community) is community assistance in terms of material assistance in the form of stockpiles, cement and energy and thoughts in equalization and/or settlement of pages in madrasah or permanent and accommodative open spaces, used for flag ceremony activities, learning sports, as well as a place to play for students, in addition to that there are also parents who donate and are even directly involved in making permanent and minimalist fencing at the main entrance of the madrasah." 14

\footnotetext{
${ }^{12}$ La Hardi, Head of MIN Keerom(Arso III), Interview, Keerom, 13 April, 2019

${ }^{13}$ La Hardi, Head of MIN Keerom, Interview, Keerom, 13 April,2019

${ }^{14}$ La Hardi, Head of MIN Keerom, Interview, Keerom, 13 April 2019
} 


\section{Talabudin Umkabu, Bahaking Ramah, Muzakkir, St. Azisah}

From the conversation, it can be seen that MIN Jaifuri Arso III, has a community (parents of students) who care about their children's education, through this Adiwiyata program, the role of the community is greater, the working group for recycling, for example, through the skilled hands of the community (Ibu Luh Manik) with the teacher. and the students who are responsible for the working group to produce various forms of handicrafts with economic value through used materials.

Besides, there are also a greenhouse and compost working group, the community (parents of students) happily build a greenhouse, where the learning hut is built on land measuring $6 \times 10$ meters, the cottage is equipped with various gardens and flowers which is useful, which is also given compost that comes from the compost working group (Bpk. Robingun). As stated by Mrs. Sumarni S.Pd.I. (teacher) as well as the person in charge of the working group for recycling.

"Participation of the community (parents of students) in this case the recycling working group, the greenhouse working group and the compost working group have produced significant results, the recycling working group through Ibu Luh Manik (community), Ibu Sumarni (teacher) and the students who joined In this working group, it has succeeded in utilizing recycled waste to produce various kinds of handicrafts that have economic value, in addition to the Green House and Compost Working Groups, where the involvement of parents of class students (I to VI) works together to build green housings. The cottage is equipped with a garden and useful flowers through a container or cup that has been packaged in such a way that it is attractive to the eye, and is given compost diapers sourced from the work of the community (Mr. Robingun), teachers, and students through the working group compost. This learning lodge serves as a means of practice for certain subjects for teachers and madrasah students." 15

The results of the interview with the Head of Islamic Elementary School alAzhar Arso IV are as follows:

"In this madrasah there is a mosque, a garden for reading al-qur'an and fencing around and equalizing the yard of the madrasah and the mosque is built which is the participation of the community both in terms of funds and from energy. Unlike the case with the provision of classes, there has not been any from the community, in my opinion, in fact the provision of classes and leadership rooms from parents or the community can be done but it requires public awareness, namely giving voluntarily because it cannot be done by dues or requests from madrasah. because it can be categorized as an illegal levy, and that is a problem faced by private madrasah because the support for facilities and infrastructure from the government is limited and from the community is also lacking."16

In line with Sugiono, (Kelapa Madrasah) was said by Mr. Sukar, the MI alAzhar teacher, that:

"The establishment of this al-Azhar Madrasah, since its establishment in 1990 and operationalized in 1994, until now is fully the suwadayah of society material, energy, and thought. MI al-Azhar is affiliated with the central

\footnotetext{
${ }^{15}$ Sumarni, (teacher) MIN Penanggung Jawab Pokja Daur Ulang, Interview, 13 April, 2019

${ }^{16}$ Sugiyono, Head of MI al-Azhar Arso IV, Interview, Keerom, 12 Mei, 2019.
} 
Islamic Education Foundation (YPIS), located in the City of Papua Province." $" 17$

When researchers want to deepen information, what kind of community involvement is meant in terms of establishing and developing madrasah. According to Mr. Sukar, (an. Head the field of curriculum) was also a senior teacher and the first person who was directly involved in the establishment of this MI al Azhar.

Furthermore, it was said by Mr. Sukar, the MI al-Azhar teacher, that:

"For example, the land on which MI al-Azhar was built and the mosque and PTQ building was a gift from Ondo Afi Arso (the owner of the wilyat rights) and he even released him. Apart from land, the MI al-Azhar building was built by the community members by working together. Cutting forest wood and other materials is entirely sourced from the community's suwadayah." 18

In line with Mr. Sukar, according to Mr. Sholikin (teacher), that the community involvement in this case the parents of students, community shops / religious teachers in the arso IV area in the development of MI al-Azhar is namely building mosques, as well as the TPQ which is integrated with madrassa, these facilities according to Mr. Sholikin. Mosques, for example, are used jointly but with the agreement that when praying in congregation with members of the community (general congregation), first the prayer, then followed by madrasah residents (teachers, staff and students). TPQ, for example, community leaders and religious teachers volunteered to teach/coaching life skill for madrasah students through extra-curricular activities, the types of activities are recitation, group prayers, memorization of al-Qur' an and calligraphy. ${ }^{19}$

Besides, during certain events such as the commemoration of Islamic holidays, this madrasah does not need to bring enlighteners from outside, enough from the Madrasah Committee/community leaders around the madrasah, as expressed by Mr. Sholikin (teacher). As follows

"In commemorating the Islamic holiday (PHBI) of this madrasah, there is no need to come from a speaker from the outside but enough representatives from the community / Madrasah Committee, the content of the lecture is by their expertise (profession) in addition to that for preparation until implementation is fully supported by the community. This greatly eases the burden on the Madrasah, both regarding funds and personnel, as well as thoughts." 20

The results of the interview with the head of Islamic Elementary School alMuthadin Arso VI are as follows:

"The madrasah is very careful in communicating with the community regarding the provision of facilities and infrastructure that are sourced from the community because they can be categorized as illegal levies. In the event of breaches of the $\mathrm{n}$ extortion carried out by unscrupulous headmaster and teachers on learners or parents of students, then sanctions are imposed fairly

\footnotetext{
${ }^{17}$ Sukar, (teacher) MI al -AzharArso IV, Deputy Head of Madrasah for Curriculum Affairs, Interview, 12 Mei, 2019

${ }^{18}$ Sukar, (teacher) MI al -AzharArso IV, Interview, 12 Mei, 2019

${ }^{19}$ Sholikin (teacher) MI al-Azhar, Interview, $12 \mathrm{Mei}, 2019$

${ }^{20}$ Sholikin (teacher) MI al-Azhar, Interview, 12 Mei, 2019
} 
heavy considering such action indicates corruption and categorized as gratuities, except in the form of donations without any request from the parties Madrasah is okay, it's just that I see the public's awareness to make voluntary contributions about existing facilities and infrastructure but not maximally."21

Furthermore, according to Ms. Suriyati, M. that assistance in the form of facilities and infrastructure that I have seen so far are:

"The community is consciously involved directly in terms of funds, materials, personnel, and even the thought of building an administrative office for the Madrasah, permanent infrastructure, digging water wells, and MCK (toilet) space. Costs come from the community."

The results of the interview with the Chairman of the Madrasah Council (the same as the Committee) / Parents of Islamic Elementary School students al-Muthadin Arso VI, are as follows:

"Indeed, there are many problems faced by the madrasah when talking about the provision of facilities and infrastructure in classrooms or other rooms, because this free education program has been socialized by local officials to the community but its delivery is just a mistake so that the delivery is less clear which results in reducing the cost of education which is often misled. Interpret it so that the community does not participate in the development of facilities and infrastructure in the form of classes and other rooms." ${ }^{23}$

The researcher made observations at the research location, and saw that the community was partially aware of the importance of participation in educational development support facilities, but it was not maximized as expected, and the community had not been directed to increase their awareness of their rights and responsibilities in education. The active participation of the community in the procurement of the main facilities and infrastructure at Islamic Elementary School of Keerom-Papua. In terms of community involvement in the delivery of education in madrasah, it is necessary so that madrasah can function properly.

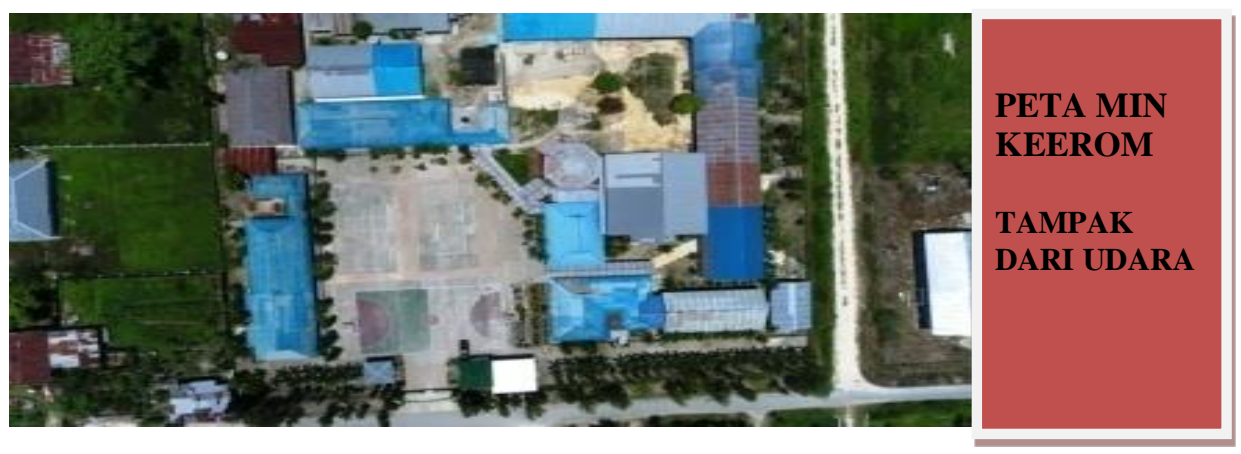

${ }^{21}$ Suriyati, M. Kepala Madrasah Ibtidaiyah al-Muthadin Arso VI, Interview, Keerom, 11 June, 2019.

${ }^{22}$ Suriyati, M. Head of Madrasah al-Muthadin Arso VI, Interview,Keerom, 11 June, 2019

${ }^{23}$ Mugio Santoso, Chairman of the Madrasah Council (Committee)/Parents of Students Madrasah Ibtidaiyah al-Muthadin Arso VI, Interview, Keerom, 27 June, 2019. 
The level of community participation in the development of standard facilities and infrastructure activities at Islamic Elementary School of Keerom-Papua, especially this main facility, does not seem to have had a major impact on the progress of madrasah, the quality of learning services in madrasah, because there are no class facilities built by the parents of students at Islamic Elementary School of KeeromPapua.
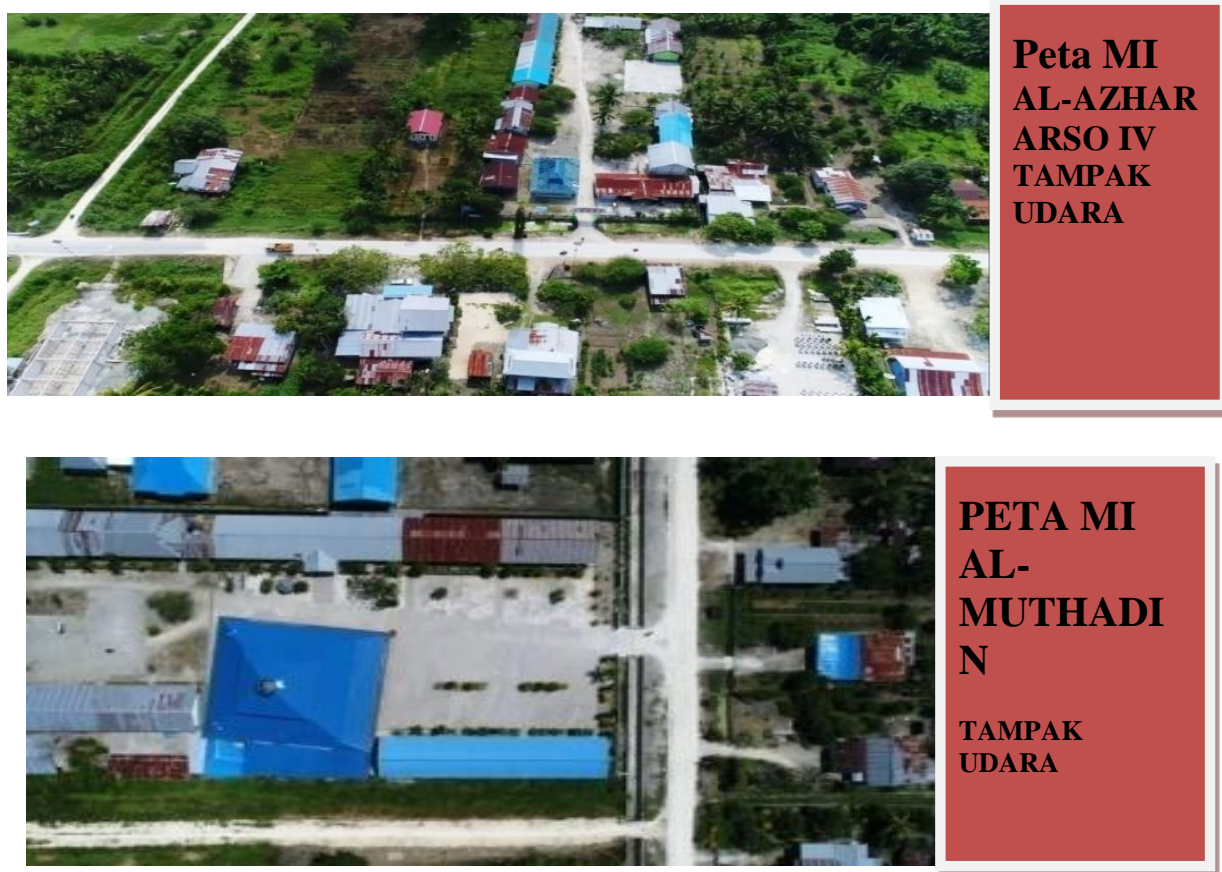

All this happens because there is no public awareness of the existence of shared responsibility in the activities of developing standard facilities and infrastructure at Islamic Elementary School of Keerom-Papua, there has not been any cooperation in the use of human resources, natural resources (environment) and artificial resources such as funds.

Then the researcher conducted a document analysis related to the development of classrooms and leadership rooms as follows:

Table 4. 1.

Main Facilities of the Keerom State Islamic Elementary School (Arso III)

\begin{tabular}{|r|r|c|c|r|}
\hline \multicolumn{2}{|c|}{ Source of funds } & \multirow{2}{*}{ Condition } & amount & \multicolumn{2}{c|}{ Room } \\
\hline Public & Government & & & Class \\
\hline & Government & Well & 12 & Lab. Computer \\
\hline & Government & Well & 1 & WC Guru \\
\hline & Government & Well & 1 & WC Students \\
\hline & Government & Well & 3 & UKS Room \\
\hline
\end{tabular}


Talabudin Umkabu, Bahaking Ramah,

Muzakkir, St. Azisah

\begin{tabular}{|c|c|c|c|r|}
\hline & Government & Well & 1 & Library \\
\hline & Government & Well & 1 & Headmaster's Room \\
\hline & Government & Well & 1 & Administration room \\
\hline Public & Government & Well & 1 & Teacher's room \\
\hline Public & & Well & 1 & Warehouse \\
\hline Public & & Well & 1 & Islamic Prayer Room \\
\hline Public & & Well & 1 & Madrasah Canteen \\
\hline Public & & Well & 1 & $\begin{array}{r}\text { Hoarding and equal } \\
\text { distribution of Madrasah } \\
\text { (Open Space) yards }\end{array}$ \\
\hline Public & & Well & 1 & $\begin{array}{r}\text { Fencing the front door of } \\
\text { the Madrasah }\end{array}$ \\
\hline & Well & 1 & $\begin{array}{r}\text { Making Madrasah fish } \\
\text { pond garden }\end{array}$ \\
\hline
\end{tabular}

Source: Islamic Elementary School Negeri Keerom (Arso III)

Based on the table above, it shows that there is community participation but has not been maximal in the development of standard facilities and infrastructure at Public Islamic Elementary School (Arso III) of Keerom-Papua is related to the main facilities, because community participation is only in the procurement of mushallah and madrasah canteen, Green House, equalization of Madrasah yards, fencing and construction of Madrasah ponds.

Table 4. 2.

Main Facilities of Islamic Elementary School al-Azhar Arso I

\begin{tabular}{|c|c|c|c|c|}
\hline \multicolumn{2}{|c|}{ Source of funds } & \multirow[b]{2}{*}{ Condition } & \multirow[b]{2}{*}{ amount } & \multirow[b]{2}{*}{ Room } \\
\hline Public & Government & & & \\
\hline & Government & Not good & 7 & Class \\
\hline & & & 0 & Lab. Computer \\
\hline & Government & Well & 1 & WC Guru \\
\hline & Government & Not good & 1 & WC Students \\
\hline & Government & Well & 1 & UKS Room \\
\hline & Government & Well & 1 & Library \\
\hline & Government & Well & 1 & Headmaster's Room \\
\hline & Government & Well & 1 & Administration room \\
\hline & Government & Well & 1 & Teacher's room \\
\hline & & & 0 & Warehouse \\
\hline
\end{tabular}




\begin{tabular}{|c|c|c|c|r|}
\hline Public & Well & 1 & Mosque/mushallah \\
\hline Public & Well & 1 & Madrasah Canteen \\
\hline Public & Well & 1 & TPQ Building \\
\hline Public & Well & 1 & Fence Around Madrasah \\
\hline Public & well & 1 & $\begin{array}{r}\text { Equitable distribution of } \\
\text { pages for mosques and } \\
\text { madrasah }\end{array}$ \\
\hline Public & & 1 & $\begin{array}{r}\text { The land used as the } \\
\text { location for Madrasah and } \\
\text { Mosque buildings is a gift } \\
\text { from traditional leaders } \\
\text { (non-Muslims). }\end{array}$ \\
\hline
\end{tabular}

Source: Madrasah Elementary al-Azhar Arso IV

Based on the table above, it shows the high public interest in participation to complement the supporting facilities for learning activities at Madrasah, it's just that it is still limited to supporting facilities, while it is still considered less involved in the development of standard facilities and infrastructure at Islamic Elementary School of Keerom-Papua relating to the main facilities (study room facilities, library, laboratory and so on).

Table 4. 3.

Main Facilities of Islamic Elementary School al-Muthadin Arso VI

\begin{tabular}{|c|c|c|c|c|}
\hline \multicolumn{2}{|c|}{ Source of funds } & \multirow[b]{2}{*}{ Condition } & \multirow[b]{2}{*}{ amount } & \multirow[b]{2}{*}{ Room } \\
\hline Public & Government & & & \\
\hline & Government & Not good & 6 & Class \\
\hline \multirow[t]{2}{*}{-} & - & - & 0 & Lab. Computer \\
\hline & Government & Well & 1 & WC Guru \\
\hline \multirow[t]{5}{*}{ Public } & & Well & 3 & WC Students \\
\hline & Government & Well & 1 & UKS Room \\
\hline & Government & Not good & 1 & Library \\
\hline & Government & Well & 1 & Headmaster's Room \\
\hline & Government & Well & 1 & Administration room \\
\hline \multirow[t]{2}{*}{ Public } & & Well & 1 & $\begin{array}{r}\text { Teacher / Administration } \\
\text { Room }\end{array}$ \\
\hline & & & 0 & Warehouse \\
\hline Public & & Well & 1 & Islamic Prayer Room \\
\hline Public & & Well & 1 & $\begin{array}{r}\text { Canteen and Madrasah } \\
\text { Cooperative }\end{array}$ \\
\hline
\end{tabular}

Source: Islamic Elementary School al-Muthadin Arso VI

Based on the table above, it can be assumed that the community does not participate in the development of standard facilities and infrastructure at Islamic Elementary School of Keerom-Papua relating to the main means.

Furthermore, the researcher examines documents related to learning tools that can be used directly in the learning process, for example books, teaching aids, writing 
Talabudin Umkabu, Bahaking Ramah,

Muzakkir, St. Azisah

tools, and practical tools. Teaching aids are educational aids which can be in the form of actions or objects that can concrete learning material.

Table 4. 4.

Teaching Aids of the Keerom State Islamic Elementary School (Arso III)

\begin{tabular}{|c|c|c|c|c|}
\hline \multicolumn{2}{|c|}{ Source of funds } & \multirow[t]{2}{*}{ Condition } & \multirow[t]{2}{*}{ amount } & \multirow[t]{2}{*}{ Form of Goods } \\
\hline Public & Government & & & \\
\hline & Government & $\begin{array}{c}\text { Good / } \\
\text { Light } \\
\text { Damage }\end{array}$ & 180 & $\begin{array}{r}\text { Table and chair to learn } \\
\text { students }\end{array}$ \\
\hline & Government & Well & 1 & The headmaster's desk \\
\hline & Government & Well & 16 & Teacher's desk \\
\hline Public & & Well & 8 & Guest chair table \\
\hline & Government & $\begin{array}{c}\text { Good / } \\
\text { Light } \\
\text { Damage }\end{array}$ & 6 & Whiteboard \\
\hline & Government & $\begin{array}{l}\text { Light } \\
\text { Damage }\end{array}$ & 4 & Bulletin board \\
\hline & Government & Well & 1 & Statistics board \\
\hline & Government & Well & 4 & Wardrobe \\
\hline & Government & Well & 10 & $\begin{array}{r}\text { Image of the president and } \\
\text { vice president }\end{array}$ \\
\hline & Government & Well & 10 & Pancasila Pictures \\
\hline & Government & Broken & 1 & Typewriter \\
\hline & Government & Well & 2 & Computer \\
\hline & Government & Well & 2 & Laptop \\
\hline & Government & Well & 2 & Clock \\
\hline & Government & Well & 1 & Bell \\
\hline & Government & Well & 7 & Indonesian map \\
\hline & Government & Well & 1 & Map of Prop. \\
\hline & Government & Well & 1 & City Map \\
\hline & Government & Well & 1 & Continent Map \\
\hline Public & & Well & 1 & Table Tennis Table \\
\hline
\end{tabular}




\begin{tabular}{|r|r|c|c|r|}
\hline & Government & Well & 1 & Language \\
\hline & Government & Well & 2 & Mathematics \\
\hline & Government & Well & 3 & Anatomy of the body \\
\hline & Government & Well & 12 & Science teaching aids \\
\hline & Government & Well & 4 & Fan \\
\hline
\end{tabular}

Source: Islamic Elementary School Negeri Keerom (Arso III)

Based on the table above, the community has participated in providing infrastructure in the form of guest tables and chairs and table tennis tables, this participation is still lacking due to the still-dominant provision of the government in developing standard facilities and infrastructure at Islamic Elementary School of Keerom-Papua relating to infrastructure.

Table 4. 5.

Infrastructure Islamic Elementary School al-Azhar Arso IV

\begin{tabular}{|c|c|c|c|c|}
\hline \multicolumn{2}{|c|}{ Source of funds } & \multirow[t]{2}{*}{ Condition } & \multirow[t]{2}{*}{ amount } & \multirow[t]{2}{*}{ Form of Goods } \\
\hline Public & Government & & & \\
\hline & Government & $\begin{array}{c}\text { Good / } \\
\text { Light } \\
\text { Damage }\end{array}$ & 160 & $\begin{array}{r}\text { Table and chair to learn } \\
\text { students }\end{array}$ \\
\hline & Government & Well & 1 & The headmaster's desk \\
\hline & Government & Well & 12 & Teacher's desk \\
\hline & Government & Well & 6 & Guest chair table \\
\hline & Government & $\begin{array}{l}\text { Good / } \\
\text { Light } \\
\text { Damage }\end{array}$ & 6 & Whiteboard \\
\hline & Government & $\begin{array}{c}\text { Light } \\
\text { Damage }\end{array}$ & 2 & Bulletin board \\
\hline & Government & Well & 1 & Statistics board \\
\hline & Government & Well & 3 & Wardrobe \\
\hline & Government & Well & 8 & $\begin{array}{r}\text { Image of the president and } \\
\text { vice president }\end{array}$ \\
\hline & Government & Well & 8 & Pancasila Pictures \\
\hline & Government & Well & 1 & Typewriter \\
\hline & Government & Well & 2 & Computer \\
\hline
\end{tabular}


Talabudin Umkabu, Bahaking Ramah,

Muzakkir, St. Azisah

\begin{tabular}{|c|c|c|c|c|}
\hline & Government & Well & 1 & Laptop \\
\hline & Government & Well & 1 & Clock \\
\hline & Government & Well & 1 & Bell \\
\hline & Government & Well & 1 & Indonesian map \\
\hline & Government & $\begin{array}{c}\text { Light } \\
\text { Damage }\end{array}$ & 1 & Map of Prop. \\
\hline & & & 1 & City Map \\
\hline & & & 1 & Continent Map \\
\hline & & & 0 & Table Tennis Table \\
\hline & & & 0 & Language \\
\hline & Government & Well & 2 & Mathematics \\
\hline & Government & $\begin{array}{c}\text { Light } \\
\text { Damage }\end{array}$ & 1 & Anatomy of the body \\
\hline & Government & $\begin{array}{c}\text { Light } \\
\text { Damage }\end{array}$ & 4 & Science teaching aids \\
\hline Public & & Well & 2 & Fan \\
\hline
\end{tabular}

Source: Islamic Elementary School al-Azhar Arso IV

If you pay attention to the table above, it shows the lack of community participation in the development of standard facilities and infrastructure at Islamic Elementary School of Keerom-Papua is related to the procurement of infrastructure, because community participation only involves the procurement of fans, apart from the government.

Table 4. 6.

Infrastructure Islamic Elementary School al-Muthadin Arso VI

\begin{tabular}{|c|c|c|c|c|}
\hline \multicolumn{2}{|c|}{ Source of funds } & \multirow[t]{2}{*}{ Condition } & \multirow[t]{2}{*}{ amount } & \multirow[t]{2}{*}{ Form of Goods } \\
\hline Public & Government & & & \\
\hline & Government & $\begin{array}{c}\text { Good / } \\
\text { Light } \\
\text { Damage }\end{array}$ & 120 & $\begin{array}{r}\text { Table and chair to learn } \\
\text { students }\end{array}$ \\
\hline & Government & Well & 1 & The headmaster's desk \\
\hline & Government & Well & 8 & Teacher's desk \\
\hline Public & & Well & 4 & Guest chair table \\
\hline & Government & $\begin{array}{r}\text { Good } / \\
\text { Light }\end{array}$ & 6 & Whiteboard \\
\hline
\end{tabular}




\begin{tabular}{|c|c|c|c|c|}
\hline & & Damage & & \\
\hline & Government & $\begin{array}{r}\text { Light } \\
\text { Damage }\end{array}$ & 1 & Bulletin board \\
\hline & Government & Well & 1 & Statistics board \\
\hline \multirow[t]{18}{*}{ Public } & & Well/ & 2 & Wardrobe \\
\hline & Government & Well & 6 & $\begin{array}{l}\text { Image of the president and } \\
\text { vice president }\end{array}$ \\
\hline & Government & Well & 6 & Pancasila Pictures \\
\hline & Government & Well & 1 & Typewriter \\
\hline & & & 0 & Computer \\
\hline & Government & Well & 1 & Laptop \\
\hline & Government & Well & 1 & Clock \\
\hline & Government & Well & 1 & Bell \\
\hline & Government & Well & 1 & Indonesian map \\
\hline & Government & $\begin{array}{c}\text { Light } \\
\text { Damage }\end{array}$ & 1 & Map of Prop. \\
\hline & & & 0 & City Map \\
\hline & & & 0 & Continent Map \\
\hline & & & 0 & Table Tennis Table \\
\hline & & & 0 & Language \\
\hline & Government & Well & 1 & Mathematics \\
\hline & Government & $\begin{array}{c}\text { Light } \\
\text { Damage }\end{array}$ & 1 & Anatomy of the body \\
\hline & & $\begin{array}{c}\text { Light } \\
\text { Damage }\end{array}$ & 2 & Science teaching aids \\
\hline & & & 0 & Fan \\
\hline
\end{tabular}

The results of the table above give an idea that the people of Keerom-Papua has not maximally participated in the standard development program for facilities and infrastructure at Islamic Elementary School of Keerom-Papua relating to the procurement of infrastructure.

Based on the results of interviews, observations, and analysis of the madrasah documents above, it shows that all facilities and infrastructure are dominant in government procurement, so it can be said that community participation in the activities of developing standard facilities and infrastructure at Islamic Elementary 


\section{Talabudin Umkabu, Bahaking Ramah, Muzakkir, St. Azisah}

School of Keerom-Papua community has not been active in participating. This suggests that the parents of students and the community are not fully aware that they have the responsibility to participate in the development of standard facilities and infrastructure at Islamic Elementary School of Keerom-Papua.

Community participation in organizing the development of standard facilities and infrastructure at Islamic Elementary School of Keerom-Papua related to the main facilities has not yet been realized due to the lack of awareness of community ownership of the existence of educational institutions which then encourages a sense of responsibility to create quality resources.

Not maximal community participation in the development of standard facilities and infrastructure at Islamic Elementary School of Keerom-Papua is related to the main facilities, because many people, especially parents of students, still think that the education of their children is fully the responsibility of the madrasah, especially the head of madrasah and teachers. The black and white results of their children's education are fully handed over to the madrasah.

Lack of maximum community participation in the development of standard facilities and infrastructure at Islamic Elementary School of Keerom-Papua which is related to the main means, the factors that cause the involvement of parents of students not fully run optimally, many circles provide a narrow understanding of people's involvement, such as only being limited to the formal presence of parents of students to the madrasah to attend meetings, take child's report card, and so on.

The cause of the lack of maximum community participation in the development of standard facilities and infrastructure at Islamic Elementary School of Keerom-Papua is related to the main facilities because many groups, especially from the madrasah, think that parents of low-income students will not be able to provide support and guidance for the education of their children, so there is less communication with the parents of students.

The cause of the lack of maximum community participation in the development of standard facilities and infrastructure at Islamic Elementary School of Keerom-Papua is related to the main facilities because of the lack of readiness of the teachers to be able to communicate with the parents of students. Including the causes of less than optimal community participation in the development of standard facilities and infrastructure at Islamic Elementary School of Keerom-Papua which is related to the main facilities because of the busy work of the parents of students so that they do not have time to be able to exchange opinions with education stakeholders at the madrasah.

One madrasah even has an inadequate library which should not be the case, because education may not be well organized if teachers and students are not supported by an adequate library. The library is a place to store and obtain information from various types of libraries. Library material is provided to help teachers and students complete tasks in the learning process. There are stored textbooks, reading books, supporting books, and other references. Both in print and electronic form that can support the achievement of educational goals.

Besides, the library is equipped with a place to read books. For teachers or students who want to read them at home, the library provides book loan services with a period of several days. Libraries allow teachers and students to expand and deepen 
the necessary knowledge. Madrasah libraries will be useful if they facilitate the achievement of the objectives of the learning process in madrasah.

The indication of these benefits is not only in the form of high student achievement, but also further. Among other things, students are willing to seek, find, filter, and assess information, are accustomed to learning by themselves, are trained to be responsible, and always follow developments in science, knowledge and technology. That is, the role of the library is not only to help complete learning tasks, but also to help academic culture. Teachers and students not only benefit from the completion of learning tasks, but will also benefit from habits to develop themselves sustainably

The state of the laboratory only exists in state madrasah, namely Islamic Elementary School Negeri Keerom (Arso III), while private madrasahs do not have laboratories in the case that laboratories are places to carry out practical learning that require special equipment. The laboratory serves as a place to solve problems, explore facts, practice scientific skills, skills, and develop scientific attitudes.

\section{Development of Physical Education and Health facilities}

One type of education at the madrasah ibtidaiyyah level is Jasmnai and Health education. Physical education and health are important subjects, because they help develop students as individuals and social creatures to grow and develop naturally. This is because the implementation of physical education prioritizes physical activities, especially sports and healthy living habits.

The process of transferring knowledge requires a tool or media to facilitate the transfer of knowledge. Media or tools in education in the world of sports can be said to be facilities and infrastructure. Sarpras in the Physical Education process must be available at the madrasah to achieve the goals in Physical Education learning in the madrasah. The existence of Physical Education facilities and infrastructure greatly affects how soon or later students master the learning material.

Physical Education Learning is not optimal because it does not have adequate facilities and infrastructure, considering that almost all sports and Physical Education require a variety of facilities and infrastructure. The need for physical education facilities and infrastructure in physical education learning is very vital, meaning that physical education learning must use facilities and infrastructure that are by the needs and how to control or how to use it. So that the facilities and infrastructure must be present in every physical education learning. Facilities and infrastructure must also meet the requirements to create an effective physical education learning process.

Sports facilities in a broad sense are the equipment that must be fulfilled by a madrasah for educational sports lessons. The outside facilities are a volleyball court, basketball court, soccer field, badminton court, tennis court and so on.

Meanwhile, indoor facilities are closed wards and can be used at any time even in rainy or bad weather. In terms of facilities, including a swimming pool. Fulfillment of facilities, gym wards, martial arts rooms and especially swimming pools, but none have been prepared yet.

Furthermore, in the description of facilities, it is only limited to the meaning of a greenfield or a sports field, where with this field children are free to run, play, compete and so on. The means of physical education are anything that is not permanent, can be carried anywhere or moved from one place to another. Examples: ball, racket, bat, stick, block and table tennis racket. Facilities or tools are very 


\section{Talabudin Umkabu, Bahaking Ramah, Muzakkir, St. Azisah}

important in motivating students to move actively, so that students to carry out activities seriously and finally the objectives of the activity can be achieved.

Sports equipment in this case is defined as meeting the needs for tools in the form of rounders, big ball number three, volleyball, baseball bats and rounders, basketball and others. If the sports equipment is difficult to fulfill in a short time, the teacher can choose the type of equipment that is considered more suitable for the facilities owned.

Basically, the government and the community are responsible for preparing educational facilities, but in reality, the government is limited in assisting, so community participation is needed. To ensure that there is community participation in the development of standard facilities and infrastructure at Islamic Elementary School of Keerom-Papua in the field of sports, the researchers conducted interviews with several informants as follows:

"In my opinion, the availability of physical education facilities and infrastructure in good condition will provide many benefits, namely: (1) Helping the implementation of the Physical Education learning process smoothly; (2) Students will be motivated by the state of the facilities and infrastructure that are complete and good, so students will be active in participating in Physical Education learning activities; (3) Assisting Physical Education teachers in the smooth running of Physical Education learning activities for students, so that there will be effective in the process of Physical Education learning activities. But frankly, in this madrasah, the sarpras condition is still not sufficient to meet the learning needs of Physical Education for students. But the facilities and infrastructure come from the government and part of the community, I am grateful that the community has participated in providing sports equipment." 24

The results of an interview with the sports teacher at Islamic Elementary School Negeri Keerom (Arso III), said that:

"Alhamdulillah, the sports facilities and infrastructure at this madrasah are adequate and all the availability of physical education facilities and infrastructure comes from the government and from the community's donations, it is evidence that the community is enthusiastic about participating in sports at this madrasah." 25

The results of the interview with the sports teacher at Islamic Elementary School al-Azhar Arso IV, said that:

"The sports facilities and infrastructure in this madrasah come from the madrasah and there are gifts from the parents of students, even students who are asked to prepare some sports equipment because in this madrasah there are not enough sports facilities, they still need to be added." 26

The results of the interview with the sports teacher at Islamic Elementary School al-Muthadin Arso VI, said that:

\footnotetext{
${ }^{24}$ La Hardi, Head of MIN Keerom(Arso III), Interview, Keerom, 13 April, 2019

${ }^{25}$ Rahman, Sport Teacher of MIN Keerom(Arso III), Interview, Keerom, 13 April, 2019.

${ }^{26}$ Jainuddin, Sport Teacher of of MI al-Azhar Arso IV, Interview, Keerom, 27 Mei, 2019.
} 
"If in this madrasah there are sports facilities and infrastructure from the government and assistance from the community is only insufficient and the conditions are not good (not supportive), that is the obstacle faced in learning activities for teachers and students. So that students are less enthusiastic about doing sports activities, data/value collection is less objective, and teachers will be hampered in delivering Physical Education material." 27

Based on the results of the interview above, the sports facilities and infrastructure in Islamic Elementary School of Keerom-Papua illustrate that the community participates in the procurement of sports facilities and infrastructure, state madrasah already have enough sports equipment, while private madrasah have not been maximized.

The existence of sports facilities at Islamic Elementary School of KeeromPapua is a facility that supports the facilities, with adequate tools, the Physical Education learning process will be ideal. With the results of the existence of sports facilities at Islamic Elementary School of Keerom-Papua which does not indicate that the existence of sports facilities at Islamic Elementary School of The existing KeeromPapua is inadequate, and there is still much that needs to be addressed.

To strengthen the results of the above interviews, the authors made observations related to sports facilities and infrastructure, as follows:

Table 4. 7.

Sports Infrastructure at Islamic Elementary School Negeri Keerom (Arso III)

\begin{tabular}{|c|r|r|r|}
\hline \multicolumn{2}{|c|}{ Source of funds } & amount & Form of Goods \\
\cline { 1 - 2 } Public & Government & & Football \\
\hline 1 & - & 1 & Table tennis bed \\
\hline 2 & 2 & 4 & Table tennis ball \\
\hline 2 & 2 & 4 & Table tennis net \\
\hline 2 & - & 1 & Takraw soccer ball \\
\hline 1 & - & 2 & relay fee \\
\hline 2 & 3 & 3 & SKJ Cassettes \\
\hline- & 2 & 2 & Tape recorder \\
\hline- & 1 & 1 & Sports clothing \\
\hline- & 2 & 6 & Tent \\
\hline 4 & 1 & 1 & Football goal \\
\hline- & - & 2 & Mini football field \\
\hline 2 & - & 1 & Badminton court \\
\hline 1 & - & 1 & Takraw field \\
\hline 1 & - & 1 & \\
\hline 1 & & & \\
\hline
\end{tabular}

${ }^{27}$ Ali Akbar, Sport Teacher of Madrasah al-Muthadin Arso VI, Interview, Keerom, 26 June, 
Talabudin Umkabu, Bahaking Ramah,

Muzakkir, St. Azisah

\begin{tabular}{|l|r|r|r|}
\hline 1 & - & 1 & Madrasah courtyard \\
\hline
\end{tabular}

Source: Islamic Elementary School Negeri Keerom (Arso III) 2019.

Based on the results of observations of sports infrastructure at Islamic Elementary School of Keerom-Papua is adequate and in terms of community participation, it can be said that the community is enthusiastic about participating in organizing sports infrastructure at Islamic Elementary School of Keerom-Papua, the public's attention to the needs of the sport of students is seen by the community paying attention to it.

Furthermore, the observation of sports infrastructure at Islamic Elementary School al-Azhar Arso IV is as follows:

Table 4.8.

Sports Infrastructure at Islamic Elementary School al-Azhar Arso IV

\begin{tabular}{|c|l|c|l|}
\hline \multicolumn{2}{|c|}{ Source of funds } & amount & \multicolumn{2}{c}{ Form of Goods } \\
\cline { 1 - 2 } Public & Government & & \\
\hline 1 & - & 1 & Foot-ball \\
\hline- & - & 0 & Badminton rackets \\
\hline- & - & 0 & Table tennis bed \\
\hline- & - & 0 & Table tennis ball \\
\hline 1 & - & 1 & Table tennis net \\
\hline 2 & - & 2 & Takraw soccer ball \\
\hline- & 2 & 2 & The baton \\
\hline- & 1 & 1 & SKJ Cassettes \\
\hline- & 1 & 1 & Tape recorder \\
\hline- & 2 & & \\
\hline- & 1 & 2 & Sports clothing \\
\hline 2 & - & 1 & Tent \\
\hline 1 & - & 2 & Football goal \\
\hline- & - & 1 & Mini football field \\
\hline 1 & - & 0 & Badminton court \\
\hline 1 & - & 1 & Takraw field \\
\hline
\end{tabular}

Source: Islamic Elementary School al-Azhar Arso IV 2019

From the results of observations at Islamic Elementary School al-Azhar Arso IV, it can be said that the public is sufficiently participating in preparing sports infrastructure at Islamic Elementary School of Keerom-Papua, although it still needs to be maximized because community participation is still lacking.

Table 4.9.

Sports Infrastructure at Islamic Elementary School al-Muthadin Arso VI

\begin{tabular}{|c|c|c|c|}
\hline \multicolumn{2}{|c|}{ Source of funds } & \multirow{2}{*}{ amount } & \multirow{2}{*}{ Form of Goods } \\
\hline Public & Government & & \\
\hline
\end{tabular}




\begin{tabular}{|l|l|l|l|}
\hline 1 & - & 1 & Foot-ball \\
\hline- & - & 0 & Badminton rackets \\
\hline- & - & 0 & Table tennis bed \\
\hline 0 & 0 & 0 & Table tennis ball \\
\hline- & - & 0 & Table tennis net \\
\hline 1 & - & 1 & Takraw soccer ball \\
\hline- & 2 & 2 & The baton \\
\hline- & 1 & 1 & SKJ Cassettes \\
\hline- & 1 & 1 & Tape recorder \\
\hline- & 2 & 2 & Sports clothing \\
\hline- & 1 & 1 & Tent \\
\hline- & - & 0 & Football goal \\
\hline- & - & 0 & Mini football field \\
\hline- & - & 0 & Badminton court \\
\hline 1 & - & 1 & Takraw field \\
\hline 1 & - & 1 & Madrasah courtyard \\
\hline
\end{tabular}

Source: Islamic Elementary School al-Muthadin Arso VI 2019

Paying attention to the sports infrastructure at Islamic Elementary School alMuthadin Arso VI is very minimal, even though the community still participates in preparing the sports infrastructure. This means that if it is related to community participation in preparing sports infrastructure, it can be said that the community participates, although it still needs to be optimized, especially the procurement of sports infrastructure in a private madrasah, because the sports infrastructure in private madrasah is very minimal.

Based on these results it can be interpreted that the existence of sports facilities at Islamic Elementary School of Keerom-Papua still needs to be completed, because the number of learning tools can affect physical education learning process. This is because with a limited number of tools, the use of tools must be alternately, so that it can reduce the effectiveness of time in the learning process. Besides, there are also broken tools that will endanger the user if the security of the tool is lacking. Even some of the tools that do not exist, are mostly not owned by Islamic Elementary School of Keerom-Papua.

The lack of physical education learning tools is closely related to the cost to fulfill the existence of these tools. Madrasah rarely receives assistance to fulfill physical education tools, so that all this time each madrasah has tried to provide for the physical education tools themselves. Therefore, the existence of Physical Education equipment in Islamic Elementary School of Keerom-Papua is not fully adequate. The inadequate results mean that madrasah has not been able to meet the overall existence of tools, tools, and physical education facilities so that community participation is needed. 


\section{CONSLUSION}

Based on the explanation above, it can be concluded that community participation in the development of standard facilities and infrastructure at Islamic Elementary School of Keerom-Papua is very enthusiastic in building mushallah/mosque and procuring canteens, greenhouses. hoarding and equalizing the madrasah yard, fencing the front door of the madrasah, making madrasah fish pond gardens, and the land used as the location for the construction of madrasah and mosques are the provision of traditional leaders (non-Muslim) and the procurement of sports equipment, while the procurement of the main facilities, specifically for Islamic Elementary School The private sector shows that there is participation but it is not maximal while public Islamic Elementary School have not seen maximum community participation, it is due to a lack of public awareness of a sense of responsibility in developing madrasah, and madrasah lacking in building communication to exchange opinions with the community about the importance of community participation in developing madrasah as a charity Jariyah and social activities.

\section{REFERENCES}

Arikunto,Suharsimi dan Lia Yuliana, Manajemen Pendidikan Yogyakarta: Aditya Media, 2008.

Bafadal,Ibrahim, Manajemen Perlengkapan Sekolah, Teori dan Aplikasi Cet. II; Jakarta: Bumi Aksara, 2004.

Minarti,Sri, Manajemen Sekolah: Mengelola Lembaga Pendidikan Secara Mandiri Yogyakarta: Ar-Ruzz Media, 2011.

Mulyasa,E., Pedomanan Manajemen Berbasis Madrasah,Bandung: Deperteman Pendidikan Agama RI., 2003.

Peraturan Menteri Pendidikan Nasiona R.I, Nomor 19 Tahun 2007 tentang Standar Pengelolaan Pendidikan oleh Stuan Pendidikan Dasar dan Menengah, (salinan lampiran.

Peraturan Pemerintah Republik Indonesia Nomor 32 Tahun 2013 Tentang Perubahan Atas Peraturan Pemerintah Nomor 19 Tahun 2005 Tentang Standar Nasional Pendidikan.

Republik Indonesia, PP Nomor 32 Tahun 2013 tentang Perubahan atas Peraturan Pemerintah Nomor 19 Tahun 2005 tentang Standar Nasional Pendidikan, pasal 1 , ayat 1 ..

Tilaar,H.A.R., Paradigma Baru Pendidikan Nasional Jakarata: Reneka Cipta, 2009.

Undang-undang dan Peraturan Pemerintah RI. 


\section{Interview Sources}

La Hardi, Head of MIN Keerom (Arso III), Interview, Keerom, 13 April, 2019

Sumarni, (teacher) MIN Penanggung Jawab Pokja Daur Ulang, Interview, 13 April, 2019

Sugiyono, Head of MIN al-Azhar Arso IV, Interview, Keerom, 12 Mei, 2019.

Sukar, (teacher) MI al-AzharArso IV, Wakil Kepala Madrasah Bidang Kurikulum, Interview, 12 Mei, 2019

Sholikin (teacher) MI al-Azhar, Interview, 12 Mei, 2019

Suriyati, M. Head of MI al-Muthadin Arso VI, Interview, Keerom, 11 June, 2019.

Mugio Santoso, Chairman of the Madrasah Council (Committee) / Parents of Students Islamic Elementary School al-Muthadin Arso VI, Interview, Keerom, 27 June, 2019.

Rahman, Sport Teacher of MIN Keerom (Arso III), Interview, Keerom, 13 April, 2019. Jainuddin, Sport Teacher of MI al-Azhar Arso IV, Interview, Keerom, 27 Mei, 2019.

Ali Akbar, Sport Teacher of MI al-Muthadin Arso VI, Interview, Keerom, 26 June, 2019. 